\title{
Etika Kristen dan Teknologi Informasi: Sebuah Tinjauan menurut Perspektif Alkitab
}

\author{
David Alinurdin* \\ *Penulis adalah dosen penuh waktu di Sekolah Tinggi Teologi SAAT Malang. \\ Email: david.alinurdin@seabs.ac.id
}

\begin{abstract}
Abstrak: Indonesia adalah negara dengan pengguna internet yang tidak bisa dianggap remeh. Menurut sebuah survei, pada tahun 2018 Indonesia menduduki peringkat keempat di dunia dalam lamanya penggunaan waktu untuk berinternet dalam sehari, yaitu 8 jam 51 menit. Maraknya penggunaan internet di Indonesia ini masih belum dibarengi dengan kualitas yang baik dalam memanfaatkan teknologi informasi ini. Pemanfaatan internet di Indonesia yang mayoritas digunakan untuk media sosial dan gaya hidup ini juga dibayangi-bayangi dengan tingkat kejahatan dan penyalahgunaan yang mengkhawatirkan. Dengan latar belakang kondisi tersebut, tulisan ini akan menyoroti aspek-aspek nilai yang memengaruhi pola pikir, sikap dan perilaku pengguna internet dari sudut pandang etika Kristen, yaitu dalam hal kesejatian relasi, pengolahan informasi, otoritas kebenaran, serta identitas dan integritas pengguna.

Kata-kata kunci: Teknologi Informasi, Internet, Etika, Konsep Nilai, Relasi, Kebenaran, Identitas, Integritas
\end{abstract}

Abstract: The number of regular internet users in the country of Indonesia should not be underestimated. At the year of 2018 it was noted that Indonesia was ranked fourth in the world in the length of time spent on the internet in a day; a total of 8 hours 51 minutes. The rise of internet use in Indonesia is not undergirded by a good quality connection in utilizing this form of information technology. The use of the Internet in Indonesia, the majority of which is used for social media and lifestyle, is also overshadowed by alarming crime and abuse rates. Keeping these observations in mind, this paper will highlight the values that influence the mindset, attitudes and behavior of internet users from the standpoint of Christian ethics, namely in terms of authenticity of relations, information processing, truth authority, and user identity and integrity.

Keywords: Information Technology, Internet, Ethics, Concepts of Value, Relations, Truth, Identity, Integrity 


\section{Pendahuluan}

Menurut laporan dari Asosiasi Penyelenggara Jasa Internet Indonesia (selanjutnya disingkat APJII), ada sekitar 143 juta orang Indonesia telah terhubung jaringan internet sepanjang tahun 2017. ${ }^{1}$ Dibandingkan dengan jumlah penduduk Indonesia yang mencapai 262 juta orang maka jumlah ini sudah mencapai hampir 55\% dari seluruh populasi. Pertambahan pengguna internet di Indonesia dari tahun 1998-2017 dapat dilihat pada gambar di bawah ini. Jika diamati, lonjakan pertambahan pengguna internet di Indonesia mulai meningkat secara signifikan sejak tahun 2009. Jika ditinjau secara global, Indonesia menempati urutan kelima dari antara negara-negara dengan penggunaan internet terbesar di dunia, setelah China, India, Amerika Serikat dan Brazil. ${ }^{2}$

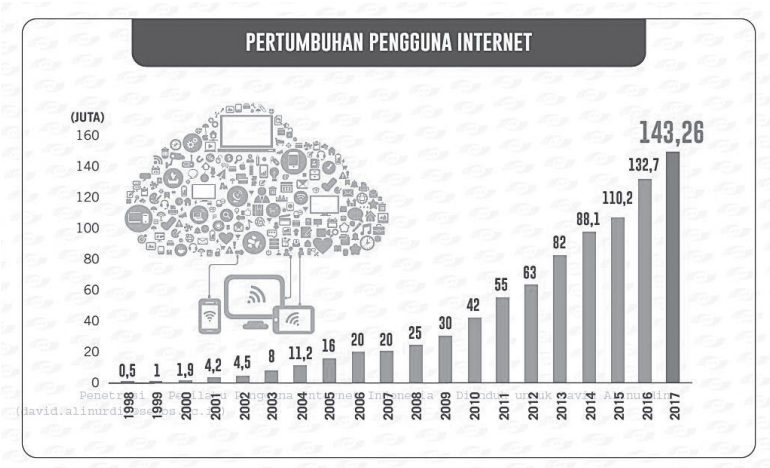

Gambar 1 Pertumbuhan Pengguna Internet di Indonesia 1998 - 2017. APJII, Perilaku Pengguna Internet Indonesia 2017 (2018), 7, Adobe PDF ebook.

Riset yang dilakukan APJII tahun 2017 kepada 2500 pengguna Internet di seluruh Indonesia menemukan bahwa mayoritas pengguna internet (72,41 persen) masih dari kalangan masyarakat urban. Secara demografis, mayoritas pengguna internet di Tanah Air adalah mereka yang berusia 19 hingga 34 tahun (49,5 persen) dengan strata ekonomi sosial menengah ke bawah (74,62 persen).

\footnotetext{
${ }^{1}$ Infografik mengenai hasil survei ini dapat diunduh di https://apjii.or.id/survei2017.

${ }^{2}$ Menurut survei Statista yang bisa diakses di https:// www.statista.com/statistics/262966/number-of-internet-users-in-selected-countries. Diakses pada 21 Agustus 2018.
}

Komposisi pengguna internet berdasarkan usia dapat dilihat pada gambar di bawah ini.

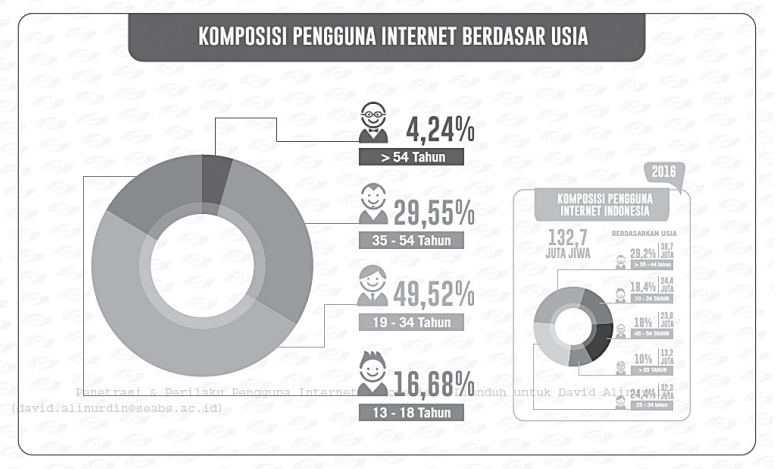

Gambar 2 Komposisi Pengguna Internet Berdasarkan Usia pada tahun 2017. APJII, Perilaku Pengguna Internet Indonesia 2017 (2018), 11, Adobe PDF ebook.

Ditinjau dari perilaku pengguna, ditemukan bahwa pengguna internet di Indonesia yang mayoritas kaum muda ini masih cenderung konsumtif dan belum serius memanfaatkan kekuatan teknologi ini untuk kegiatan produktif (seperti perbankan, jual beli barang atau kegiatan ekonomi lainnya). Internet sebagian besar masih digunakan oleh masyarakat Indonesia untuk sekadar chatting, berjejaring sosial di dunia maya, browsing, atau sekadar untuk melihat foto dan menyaksikan video. Beberapa infografik di bahwa ini memperlihatkan perilaku pengguna internet di Indonesia pada tahun 2017.

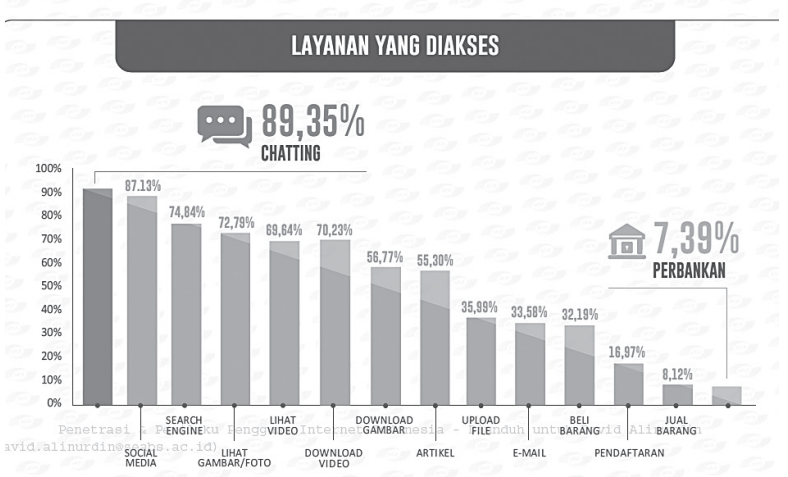

Gambar 3 Layanan yang Diakses Pengguna Internet di Indonesia pada tahun 2017. APJII, Perilaku

Pengguna Internet Indonesia 2017 (2018), 28, Adobe PDF ebook. 


\section{PEMANFAATAN INTERNET BIDANG EKONOMI}

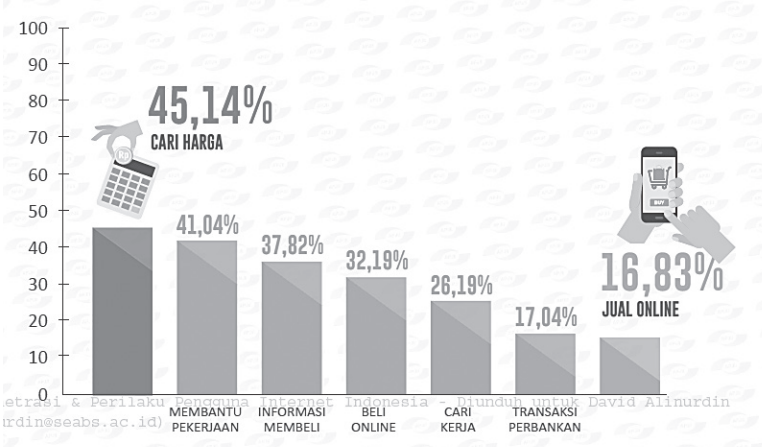

PEMANFAATAN INTERNET BIDANG LAYANAN PUBLIK

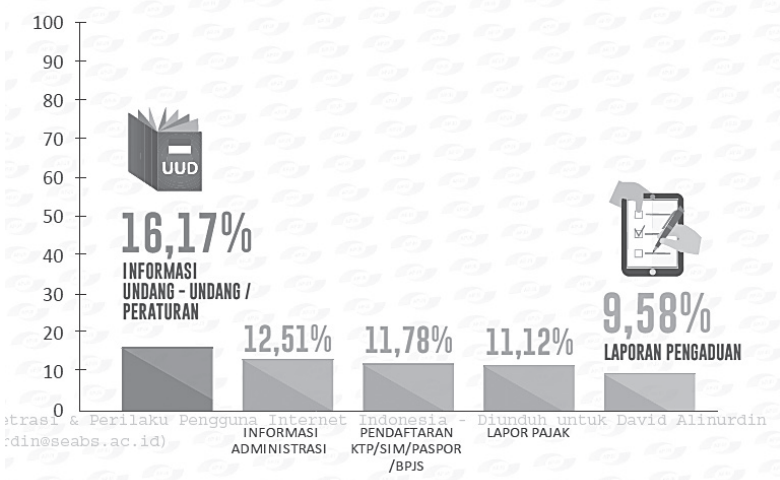

Gambar 4 Pemanfaatan Internet di Indonesia Bidang Ekonomi dan Layanan Publik. APJII, Perilaku Pengguna Internet Indonesia 2017 (2018), 29-30, Adobe PDF ebook.
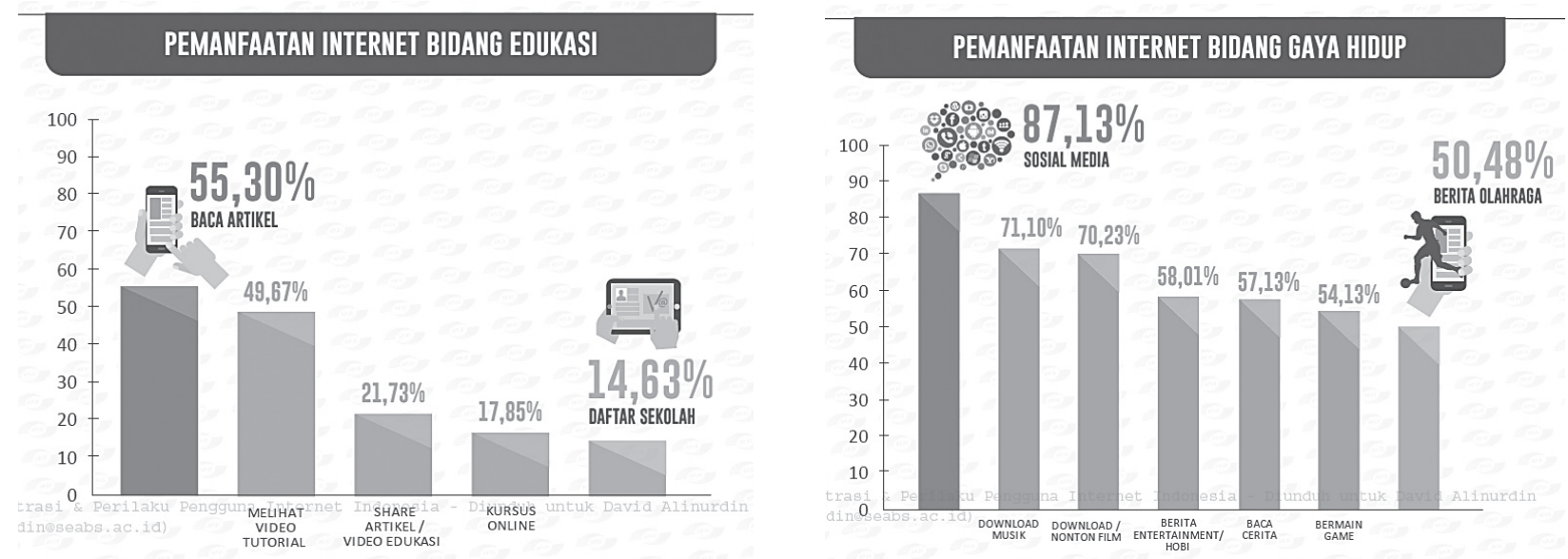

Gambar 5 Pemanfaatan Internet di Indonesia Bidang Edukasi dan Gaya Hidup. APJII, Perilaku Pengguna Internet Indonesia 2017 (2018), 31-32, Adobe PDF ebook.

Penggunaan teknologi internet di Indonesia yang kurang optimal ini juga dibayangbayangi dengan tingkat kejahatan dunia maya di Indonesia yang kian mengkhawatirkan. Menurut data yang muncul dalam acara Indonesia Cyber Crime Summit di Institut Teknologi Bandung (ITB) pada Oktober 2014, Indonesia menjadi negara nomor satu di dunia yang paling banyak mendapatkan serangan di dunia maya. ${ }^{3}$ Dimitri Mahayana, direktur lembaga riset Telematika Sharing Vision yang melakukan penelitian pada 2013, mengatakan

${ }^{3}$ Reza Wahyudi, "Kejahatan Dunia Maya di Indonesia Mengkhawatirkan,” Kompas.com, Bandung 2014, diakses 21 Agustus 2018, http://tekno.kompas.com/

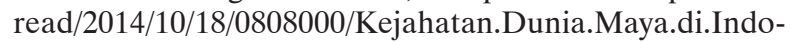
nesia.Mengkhawatirkan.
Indonesia mendapat 42.000 serangan di dunia maya per hari, yang bisa merongrong keamanan perusahaan dan negara. Riset terhadap 151 responden media sosial menunjukkan, kasus bertemu akun palsu sebanyak 22 persen, kata kunci diketahui orang lain 13,6 persen, dan pencurian akun sebanyak 9,9 persen. Hal ini tergolong berbahaya, bahkan beberapa kasus di antaranya berujung pada kekerasan yang dilakukan anak di bawah umur, kejahatan seksual, dan kasus penculikan.

Sementara itu, menurut riset yang dilakukan perusahaan keamanan komputer Symantec, Indonesia menempati peringkat ke-22 sebagai negara yang paling sering melakukan serangan 
cyber di tahun 2013. ${ }^{4}$ Peringkat Indonesia saat ini meningkat dibandingkan tahun 2012 yang menempati urutan 23 dari 157 negara yang diriset. Menurut data Symantec, aktivitas kejahatan internet dengan program jahat (malicious code atau malware ${ }^{5}$ ) yang berasal dari Indonesia menduduki peringkat keempat di tahun 2014. Sementara untuk kejahatan internet dengan cara mengirim pesan spam atau pesan yang tidak dikehendaki penerima, Indonesia menempati urutan ke- 25 . Selain itu, Indonesia juga menempati urutan ke-27 dalam aktivitas kejahatan pengelabuan (phishing ${ }^{6}$ ) dan penyerangan ke situs internet suatu negara.

Data yang lebih baru memperlihatkan bahwa keamanan berinternet di Indonesia harus semakin diperhatikan dan ditingkatkan. Kementerian bidang Politik, Hukum dan Keamanan menyatakan bahwa pada tahun 2015 kejahatan internet di Indonesia meningkat 33 persen dibandingkan tahun sebelumnya. $^{7}$ Dari kasus kejahatan internet yang terjadi, sebanyak 54,5 persen diarahkan pada situs-situs belanja daring. Di samping itu, Direktorat Siber Mabes Polri melaporkan bahwa pada tahun 2018 terdapat sekitar empat ribuan kasus terkait kejahatan siber

\footnotetext{
${ }^{4}$ Aditya Panji, "Indonesia Peringkat 22 Pelaku Kejahatan Online," Kompas.com, Jakarta 2014, diakses 21 Agustus 2018, http://tekno.kompas.com/read/2014/05/07/1719331/ indonesia.peringkat.22.pelaku.kejahatan.online.
}

${ }^{5}$ Malware atau malicious software adalah perangkat lunak yang diciptakan oleh seseorang dengan tujuan jahat yang merugikan orang lain. Malware dapat mengubah data (menghapus, menyembunyikan atau mencuri), serta menghabiskan bandwith dan juga sumber daya lain tanpa seijin pemilik komputer.

${ }^{6}$ Dalam dunia komputer, phishing adalah suatu bentuk penipuan yang dicirikan dengan percobaan untuk mendapatkan informasi peka, seperti kata sandi dan kartu kredit, dengan menyamar sebagai orang atau bisnis yang tepercaya dalam sebuah komunikasi elektronik resmi, seperti surat elektronik atau pesan instan. Istilah phishing dalam bahasa Inggris berasal dari kata fishing ('memancing'), dalam hal ini berarti memancing informasi keuangan dan kata sandi pengguna.

${ }^{7}$ T.n., "Cyberattacks in Indonesia Rising at Alarming Rate: Officials," The Jakarta Post, Jakarta 2016, diakses 21 Agustus 2018, https://www.thejakartapost. com/news/2016/06/03/cyberattacks-in-indonesia-rising-at-alarming-rate-officials.html. yang korbannya mayoritas adalah perusahaan daripada individu. ${ }^{8}$

Selain rentan menjadi korban atau bahkan pelaku kejahatan di dunia maya, penggunaan Internet di Indonesia juga cenderung menjurus kepada gejala kecanduan. Dalam sebuah riset yang dilakukan oleh HootSuite dan We Are Social didapati bahwa Indonesia menempati urutan keempat dari negara-negara di dunia dengan penggunaan internet tertinggi, yaitu rata-rata 8 jam 51 menit dalam sehari. ${ }^{9}$

Dengan melihat fenomena yang terjadi di dalam perkembangan penggunaan Internet di Indonesia yang seperti demikian, maka artikel ini dibuat dengan tujuan untuk memberikan perspektif Kristen berkaitan dengan isuisu etika yang terjadi dalam dunia teknologi informasi. Pengertian "teknologi informasi" yang dimaksud di sini adalah semua teknologi berbasis komputer yang memampukan seseorang untuk mengumpulkan, menyimpan, mengakses dan bertukaran segala jenis informasi, seperti teks singkat, tulisan, gambar dan video yang dikomunikasikan melalui internet. ${ }^{10}$

\section{Isu Etika dalam Dunia Teknologi Informasi}

Isu-isu etika dalam dunia teknologi informasi saat ini dapat digolongkan menjadi dua, yaitu kejahatan internet dan penyimpangan penggunaan Internet. Kejahatan Internet secara umum diartikan sebagai tindakan kriminal dengan meretas situs internet untuk tujuan yang jahat (misalnya menyusupkan content yang tidak baik atau virus, malware, dan

${ }^{8}$ Danang Sugianto, "4000 Laporan Cyber Crime Mayoritas Korbannya Perusahaan,” Detik Finance, Jakarta 2018, diakses 21 Agustus 2018, https://finance.detik.com/bursa-dan-valas/d-4398592/4000-laporan-cyber-crime-mayoritas-korbannya-perusahaan.

${ }^{9}$ Simon Kemp, "Digital in 2018: World's Internet Users Pass the 4 Billion Mark," We Are Social, New York 2018, diakses 21 Agustus 2018, https://wearesocial.com/ blog/2018/01/global-digital-report-2018.

${ }^{10}$ Quentin J. Schultze, Habist of the High-Tech Heart: Living Virtuously in the Information Age (Grand Rapids: Baker, 2002), 16. 
spyware $^{11}$ ) atau mengelabui dengan berbagai cara untuk mendapatkan identitas akun orang lain yang dipakai untuk tujuan yang tidak baik (misalnya menggunakan identitas kartu kredit milik orang lain untuk berbelanja, menggunakan akun milik orang lain untuk menipu, menghasut, memfitnah).

Perilaku menyimpang dalam penggunaan internet adalah seperti cybersex dan cyberaffair, sexting dan pornografi, cyberstalking dan cyberbullying, judi di internet, dan kecanduan internet. Cybersex adalah tindakan bermain peran (role-play) seksual secara virtual melalui internet di mana dua orang atau lebih saling bertukaran pesan atau gambar yang menjelaskan pengalaman dan fantasi seksual mereka. ${ }^{12}$ Cybersex dapat melibatkan masturbasi dan dalam beberapa kasus dapat berakibat pada perjumpaan seksual secara nyata. Cybersex kemudian akan berkembang menjadi cyber-affair, atau perselingkuhan secara virtual. Sexting adalah tindakan dua orang yang saling mengirimkan gambar atau video diri mereka sendiri dalam keadaan tanpa busana, melalui pesan teks. Sexting dapat berakibat pada kemungkinan tindakan pornografi melalui internet. ${ }^{13}$ Cyberstalking secara umum berarti tindakan menggunakan internet, email atau alat komunikasi elektronik lainnya untuk menguntit orang lain di dunia maya. ${ }^{14}$ Tindakan menguntit itu secara umum meliputi beberapa bentuk tindakan mengangggu dan mengancam yang dilakukan berulang kali. Dalam beberapa kasus dapat mengakibatkan sang korban, yang sudah tidak tahan lagi, akhirnya melakukan bunuh diri. Cyberbullying, yang masih erat hubungannya dengan cyberstalking, biasanya terjadi pada anak-anak dan remaja, yang diganggu,

\footnotetext{
${ }^{11}$ Spyware atau perangkat pengintai adalah istilah teknologi informasi yang mengacu kepada salah satu bentuk perangkat lunak mencurigakan yang memasang dirinya sendiri ke dalam sebuah sistem untuk mencuri data pengguna atau merusak sistem pengguna tersebut.
}

${ }^{12}$ Archibald D. Hart dan Sylvia Hart Frejd, The Digital Invasion (Grand Rapids: Baker, 2013), 117.

${ }^{13}$ Hart dan Frejd, The Digital Invasion, 119.

${ }^{14}$ Ibid., 120. direndahkan, atau dibuat merasa malu oleh teman-temannya. Di dunia maya, tindakan bullying ini sekarang tidak lagi hanya didominasi oleh anak-anak yang pemberani dan berbadan besar, melainkan juga oleh mereka yang di dunia nyata dianggap penakut, karena sekarang mereka bisa melakukannya dengan cara yang aman. ${ }^{15}$

Dengan melihat berbagai permasalahan di atas, maka sangat diperlukan sebuah kompas atau pedoman etika berdasarkan kebenaran firman Tuhan. Karena etika berkenaan dengan konsep nilai (apa yang seharusnya, yang baik dan yang benar), maka dalam artikel ini tidak akan dibahas pendekatan-pendekatan pastoral konseling ${ }^{16}$ untuk mengobati perilaku menyimpang dalam penggunaan Internet atau tips-tips praktis dan teknikteknik ${ }^{17}$ bagaimana berinternet secara aman. Sebaliknya, penulis menyoroti apa yang ada di balik semua kejahatan dan penyimpangan yang ada sehingga membentuk aspek-aspek nilai yang memengaruhi pola pikir, sikap dan perilaku para pengguna internet. Dari seluruh isu etika teknologi informasi yang dijelaskan di atas, penulis memilih untuk mengevaluasi empat aspek nilai, yaitu berkaitan dengan (1) media, identitas dan relasi; (2) informasi, pengetahuan dan hikmat; (3) kebenaran, epistemologi dan otoritas; dan (4) visibilitas, privasi dan integritas. Empat aspek nilai tersebut kemudian akan dievaluasi dari perspektif firman Tuhan.

\footnotetext{
${ }^{15}$ Ibid., 121.

${ }^{16}$ Pendekatan pastoral konseling untuk mengatasi dan menyembuhkan penyimpangan penggunaan internet dapat dilihat pada buku Hart dan Frejd, The Digital Inva-
} sion.

${ }^{17}$ Untuk mengetahui tips-tips praktis dan teknis mengenai keamanan dalam berinternet dapat dilihat pada buku Daniel J. Lohrmann, Virtual Integrity: Faithfully Navigating the Brave New Web (Grand Rapids: Brazos, 2008). Atau bisa juga melihat buku elektronik panduan berinternet secara sehat dan aman yang bisa diunduh pada www. internetsehat.org. 


\section{Media, Identitas dan Relasi}

Kemajuan teknologi informasi dan komputer telah memperkaya (dan sekaligus membombardir) kehidupan manusia saat ini dengan berbagai media. Sosiolog dan penulis Todd Gitlin mengatakan bahwa pengalaman hidup manusia saat ini telah menjadi pengalaman di dalam kehadiran media. ${ }^{18}$ Belum pernah terjadi di dalam sejarah bahwa manusia menghabiskan lebih banyak waktunya dengan menatap layar daripada berelasi dengan orang-orang lainnya.

Secara sederhana, media atau medium dapat didefinisikan sebagai sesuatu yang berada di antara. ${ }^{19}$ Dalam kaitan dengan komunikasi dan informasi melalui teknologi komputer, maka medium adalah alat atau perangkat teknologi yang berada di antara pengirim pesan dan penerima pesan, untuk menyampaikan data atau informasi berupa teks, gambar dan video. Contoh konkretnya adalah perangkat keras seperti komputer desktop, notebook/ netbook, smartphone dan tablet, yang dikendalikan oleh aplikasi perangkat lunak seperti Whatsapp, Facebook, dan YouTube melalui sistem operasi seperti Android, iOS, dan Windows dengan menggunakan jaringan seluler dan internet.

Masalah apa yang timbul dengan cara berkomunikasi melalui teknologi media seperti ini? Pertama, lahirnya dis-inkarnasi digital yang juga menghadirkan gnostisisme baru. ${ }^{20}$ Ketika teknologi informasi menjadi media yang "berdiri di antara" manusia untuk meningkatkan, mempercepat dan memperluas komunikasi, maka manusia cenderung merentangkan dirinya melampaui kehadirannya secara fisik. Seperti pandangan gnostisisme yang menganggap aspek yang tidak terlihat dari manusia (jiwa dan roh) lebih baik dan lebih tinggi

${ }^{18}$ Todd Gitlin, "Media Saturation and the Increasing Velocity of Everyday Life," dalam Living in the Information Age: A New Media Reader, ed. Erik P. Bucy (Belmont: Wadsworth, 2004), 140.

${ }^{19}$ Tim Challies, The Next Story: Life and Faith After Digital Explosion (Grand Rapids: Zondervan, 2011), 91.

${ }^{20}$ Ibid., 97-101. kualitasnya dibandingkan aspek yang terlihat (tubuh jasmani), maka manusia jadi cenderung menganggap komunikasi dan relasi di dunia maya jauh lebih baik dan lebih tinggi tingkatannya dibandingkan komunikasi dan relasi secara langsung di dunia nyata. Manusia jadi diarahkan untuk melihat dunia maya lebih superior dibandingkan dunia nyata karena dunia maya telah menjadi tempat yang memungkinkan manusia untuk mengalami kebebasan yang sejati dengan menerobos batasan-batasan fisik dan lingkungannya. ${ }^{21}$

Permasalahan kedua yang dapat terjadi dengan teknologi media saat ini adalah manusia menjalani kehidupannya dengan identitas ganda, yang satu di dunia nyata dan yang lainnya di dunia maya. Kedua identitas ini dapat tidak sama, atau dengan kata lain seseorang dapat saja menjalani dua kehidupan yang berbeda antara di dunia nyata dan di dunia maya. Identitas seseorang di dunia maya mungkin saja bukan identitas yang sebenarnya atau palsu (pseudonim). Teknologi media saat ini yang telah menjadi "kendaraan" gnostisisme baru, sedang mempromosikan "fluiditas identitas." Identitas seseorang tidaklah tetap dan tunggal melainkan dapat berubah-ubah dan

\footnotetext{
${ }^{21}$ Dalam bukunya The Soul in Cyberspace, Douglas Groothuis menceritakan seorang wanita yang menderita fobia sosial serius yang membuatnya sering mengalami kecemasan ketika berada dalam situasi sosial kehidupan sehari-hari. Akibatnya, wanita itu merasa terisolasi dari dunia dan kesepian. Tetapi, melalui teknologi internet, ia mampu untuk menemukan orang-orang lain yang juga menderita kondisi yang sama dengan dirinya. Bersamasama mereka mampu saling berinteraksi dan membentuk semacam komunitas di dunia maya. Wanita itu menemukan persahabatan dan komunitas yang tidak dialaminya di dunia nyata. Di dalam dunia maya yang tanpa tubuh dan segala kelemahan fisiknya, ia menemukan sebuah tempat dan kebebasan untuk menjadi dirinya sendiri. Namun, apakah wanita itu sungguh-sungguh menemukan kebebasan yang sejati dari segala kelemahan fisiknya? Di satu sisi memang benar wanita itu sudah mampu untuk menemukan cara mengatasi ketidakmampuannya untuk berkomunikasi. Tetapi, di sisi lain, sesungguhnya ia belum mengalami kebebasan sama sekali karena ia masih terikat dengan kondisinya, yang telah menghambatnya untuk menemukan dan mengalami komunitas sejati di dunia nyata. Wanita itu masih terkungkung oleh keempat tembok yang menghalanginya dari dunia darah dan daging. Dunia maya sebenarnya hanya memberikan ilusi kebebasan, bukan kebebasan yang sejati (The Soul in Cyberspace [Grand Rapids: Baker, 1997], 38).
} 
lebih dari satu. ${ }^{22}$ Pascamodernisme saat ini memberitahukan kepada manusia bahwa mereka dapat menjadi siapa pun yang mereka inginkan, apakah pria, wanita, gay, lesbian, keduanya sekaligus (biseks) atau tidak keduanya sama sekali. ${ }^{23}$

Permasalahan ketiga masih berkaitan dengan permasalahan yang kedua, yaitu keraguan apakah relasi yang dibangun di dunia maya oleh individu-individu yang bebas semaunya sendiri mengubah identitas mereka adalah relasi yang sejati ataukah relasi yang palsu berbentuk individualisme gaya baru. Pada tahun 2003, seorang sosiolog bernama Barry Wellman memperkenalkan sebuah istilah untuk menggambarkan komunitas dunia maya yang terjadi saat ini, yaitu networked individualism (individualisme yang terhubung dalam jaringan internet). ${ }^{24}$ Wellman mengamati bahwa para pengguna teknologi media digital saat ini tidak lagi mengidentifikasi dirinya dengan kelompok lokal di mana ia berada (seperti keluarga, kelompok etnis atau masyarakat tertentu) melainkan dengan jaringan yang tersebar luas dan acak secara geografis. Fondasi sebuah komunitas sudah bergeser, bukan lagi didasarkan pada kelompok lokal melainkan pada individu-individu yang dapat membangun komunitas menurut keinginan mereka sendiri. Semua orang sekarang sekarang dapat terhubung bersama, namun tidak lagi sebagai sebuah kelompok lokal menurut definisi tradisional, melainkan menjadi sebuah jaringan individu-individu. Komunitas dunia maya ini terbentuk bukan berdasarkan kesamaan lokasi melainkan kesamaan minat. Tanpa ikatan secara geografis, etnis atau genetik, apakah komunitas ini dapat memiliki alasan yang kuat untuk saling memperhatikan dan memedulikan secara tulus? Ataukah, mereka lebih peduli dengan minat dan kepentingan pribadi masing-masing?

Bagaimanakah perspektif firman Tuhan mengenai relasi dan komunitas yang sejati

${ }^{22}$ Ibid., 26.

${ }^{23}$ Challies, The Next Story, 102.

${ }^{24}$ Ibid., 104. menjawab berbagai permasalahan di atas? Allah sesungguhnya menghendaki manusia menjalin relasi secara langsung, muka dengan muka, dengan diri-Nya dan dengan sesamanya. Dalam Kejadian 3:8 dikatakan bahwa Allah berjalan-jalan di Taman Eden untuk menjalin relasi yang langsung (im-mediate $=$ tanpa perantara) dengan Adam dan Hawa. Dosa dan ketidaktaatan manusia kepada Allah telah mengakibatkan relasi yang langsung dengan Allah itu menjadi rusak sehingga Allah yang Mahakudus harus menyediakan perantara (medium) supaya bisa berelasi dengan umat-Nya. Karena semua bentuk perantaraan antara Allah dan umat-Nya di sepanjang sejarah (seperti Kemah Suci, Bait Suci, para imam, nabi dan ritual-ritual keagamaan) memiliki keterbatasan, maka Allah sendiri datang ke dunia di dalam diri AnakNya, Yesus Kristus, untuk meniadakan semua medium yang tidak sempurna itu dan memulihkan relasi yang langsung dengan umatNya. Allah menjanjikan bahwa di dalam kepenuhan karya penebusan-Nya, di dalam langit dan bumi yang baru, manusia akan sekali lagi mengalami kehadiran-Nya secara langsung, muka dengan muka dan menikmati kepenuhan hidup yang sejati di dalam Dia (Bil. 6:24-26; 1Kor. 13:12; Why. 22:4). Rasul Yohanes yang menyadari keinginan hati Allah ini, mengatakan kepada jemaat yang menjadi penerima suratnya, "Sungguhpun banyak yang harus kutulis kepadamu, aku tidak mau melakukannya dengan kertas dan tinta, tetapi aku berharap datang sendiri kepadamu dan berbicara berhadapan muka dengan kamu, supaya sempurnalah sukacita kita" (2Yoh. 1:12). Menyadari keterbatasan teknologi media tulisan, Yohanes rindu bisa bertatap muka langsung dengan jemaatnya, karena itulah relasi yang sejati yang bisa membawa kepenuhan dan sukacita. Namun demikian, ia pun menyadari adanya keterbatasan jarak fisik antara dirinya dengan mereka, sehingga dengan pertolongan inspirasi Roh Kudus ia pun tetap menggunakan media tulisan surat supaya bisa mengatasi keterbatasan fisik itu 
dan tetap bisa menjalin relasi yang membangun jemaatnya. ${ }^{25}$

Firman Tuhan juga mengajarkan tentang membangun relasi yang tulus tanpa kepurapuraan di dalam sebuah komunitas. Rasul Paulus menasihatkan jemaat di Roma, "Hendaklah kasih itu jangan pura-pura!" (Rm. 12:9a). Kepada jemaat di Korintus yang meragukan integritasnya, Paulus berkata, "Suara hati kami memberi kesaksian kepada kami bahwa hidup kami di dunia ini, khususnya dalam hubungan kami dengan kamu, dikuasai oleh ketulusan dan kemurnian dari Allah bukan oleh hikmat duniawi, tetapi oleh kekuatan kasih karunia Allah" (2Kor. 1:12). Kepada jemaatnya, rasul Petrus pun menasihati supaya demi ketaatan kepada kebenaran, mereka dapat "mengamalkan kasih persaudaraan yang tulus ikhlas, ... bersungguhsungguh saling mengasihi dengan segenap hatimu" (1Ptr. 1:22). Dan, sebuah komunitas yang sejati menunjukkan kasih tulus mereka "bukan dengan perkataan atau dengan lidah, tetapi dengan perbuatan dan di dalam kebenaran" (1Yoh. 3:18).

Di tengah kecanggihan teknologi media menawarkan bentuk baru di dalam berkomunikasi, berelasi dan berkomunitas, bagaimanakah orang Kristen menyikapi hal ini? Pertama, kita tidak boleh jatuh ke dalam pragmatisme dengan membiarkan kenyamanan dan kemudahan menjadi standar baru yang mengesampingkan apa yang lebih baik atau terbaik di dalam berkomunikasi dan berelasi. Misalnya, orang-orang saat ini cenderung menghindari percakapan tatap muka langsung atau percakapan suara melalui telepon dan lebih memilih mengirimkan teks melalui SMS, email, aplikasi chatting, dan media sosial karena dianggap lebih mudah, nyaman dan memberikan rasa aman. Kedua, kita perlu menyadari bahwa membangun komunikasi, relasi dan komunitas yang baik dan sehat tidaklah terjadi dalam satu malam karena diperlukan waktu yang cukup banyak dan usaha yang

\footnotetext{
${ }^{25}$ John Dyer, From the Garden to The City: The Redeeming and Corrupting Power of Technology (Grand Rapids: Kregel, 2011), 30.
}

tekun. Karena itu, di dalam setiap komunikasi dan relasi yang sedang dibangun, sebaiknya kita menghadirkan diri secara langsung, mendedikasikan waktu secara khusus, menghindari pendekatan instan dan menjauhkan diri dari segala bentuk distraksi teknologi yang dapat mengganggu komunikasi.

\section{Informasi, Pengetahuan dan Hikmat}

Dengan munculnya berbagai teknologi baru dalam dunia komputer dan Internet yang memudahkan manusia memperoleh informasi dari berbagai belahan dunia secara instan maka zaman ini dapat dikatakan sebagai zaman di mana manusia mengalami "information overload" atau yang juga biasa disingkat dengan TMI (Too Much Information). ${ }^{26}$ Permasalahan apa yang muncul dari keberlimpahan informasi yang melanda hidup manusia saat ini?

Pertama, manusia jadi keranjingan, dan bahkan cenderung mendewakan informasi. Melihat gejala dan perilaku manusia yang demikian, Quentin Schultze memberi peringatan bahwa manusia sudah terjebak ke dalam informasionisme, yaitu iman yang tidak peka, tidak bijak, dan kosong kepada pengumpulan dan penyebaran informasi sebagai jalan untuk mencapai kemajuan sosial dan kesenangan pribadi. ${ }^{27}$ Informasi telah menjadi standar tertinggi yang melaluinya manusia memahami diri dan kehidupannya.

Permasalahan kedua, karena teknologi komputer saat ini sedemikian banyak, cepat dan mudah di dalam menyajikan berbagai informasi, maka manusia jadi menekankan aspek "adalah" lebih utama daripada aspek "seharusnya," atau dengan kata lain, manusia hanya mementingkan untuk mencari dan memperoleh sebanyak mungkin informasi daripada memikirkan, menganalisis, mengolah dan merenungkan semua informasi itu untuk menemukan kebenaran. Hasil akhir

\footnotetext{
${ }^{26}$ Craig Detweiler, iGods: How Technology Shapes Our Spiritual and Social Lives (Grand Rapids: Brazos, 2013), 107-111.

${ }^{27}$ Schultze, Habits of The High-tech Heart, 26.
} 
dari berlimpahnya informasi di dalam kehidupan modern saat ini tidaklah menjadikan manusia lebih bijak dan bajik, malah sebaliknya manusia jadi berpikir secara dangkal atau malah lebih suka tidak berpikir sama sekali.

Permasalahan kedua membawa kita kepada permasalahan ketiga, yaitu "outsourcing of memory." ${ }^{28}$ Karena kecanggihan teknologi informasi membuat semua informasi itu amat berlimpah dan mudah diakses sedemikian cepat maka manusia berpikir ia tidak perlu lagi mengingat, menghafal atau menyimpan informasi itu di dalam pikirannya. Hanya dengan sekali klik semuanya itu mudah didapat dari internet melalui mesin pencari (search engine). Hal ini semakin diperkuat dengan lahirnya teknologi cloud, yang menawarkan tempat penyimpanan digital dengan kapasitas besar dan gratis. Di sinilah orang pada umumnya menyimpan dan mengarsip semua informasi yang diperolehnya, bahkan termasuk data-data pribadinya.

Bagaimana perspektif firman Tuhan menjawab kecenderungan dan permasalahan di atas? Tuhan menghendaki manusia bukan hanya sekadar menjadi pengumpul informasi melainkan pemikir yang dewasa. Kepada jemaat Korintus, Paulus berkata, "Janganlah sama seperti anak-anak dalam pemikiranmu. Jadilah anak-anak dalam kejahatan, tetapi orang dewasa dalam pemikiranmu!" (1Kor. 14:29). Dan lebih dari itu, Tuhan juga menghendaki manusia mengejar dan mencintai hikmat yang lahir dari sikap takut akan Dia, dan bukan hanya sekadar mendapatkan pengetahuan yang banyak (Ams. 1, 3,4:7; 9:10; Yak. 1:5). Dalam rangka untuk memperoleh hikmat dan pengertian akan kebenaran, Tuhan juga memerintahkan manusia untuk mengingat setiap firman-Nya dan perbuatanperbuatan-Nya yang telah dikerjakan-Nya di dalam kehidupan mereka (Ul. 6; Yos. 1; Mzm. 1; Luk. 22:1).

Sejalan dengan firman Tuhan di atas, pada tahun 1980an, Russell Ackoff, profesor di Wharton School dari University of

${ }^{28}$ Challies, The Next Story, 150.
Pennsylvania memopulerkan apa yang dikenal sebagai DIKW, yang prosesnya demikian: ${ }^{29}$

\section{Data $\rightarrow$ Information $\rightarrow$ Knowledge $\rightarrow$ Wisdom}

Pada tingkat yang paling mendasar, data berarti simbol-simbol seperti huruf, angka dan emoticon. Data-data ini tidak memiliki arti apa-apa di luar konteksnya. Ketika data itu dikumpulkan, terciptalah informasi yang menjawab pertanyaan-pertanyaan dasar seperti: apa, siapa, di mana dan bagaimana? Informasi adalah data-data yang sudah dihubungkan dan memiliki arti tertentu. Ketika data-data dikumpulkan, disusun sedemikian rupa, dan dibandingkan satu sama lain maka kita mendapatkan knowledge (pengetahuan). Pengetahuan telah membuat informasi menjadi bermanfaat. Dan terakhir, ketika pengetahuan digunakan untuk mengambil sebuah keputusan, maka pengetahuan yang telah diterapkan ke dalam situasi kehidupan itu telah berubah menjadi hikmat. Hikmat menggabungkan sejumlah pengetahuan dengan pengalaman supaya manusia bisa hidup bajik.

Bagaimanakah sikap orang Kristen di dalam menghadapi teknologi informasi saat ini yang menawarkan segudang informasi secara mudah dan cepat? Kita perlu memilah-milah manakah informasi yang penting, dibutuhkan dan bermanfaat untuk diketahui serta manakah yang boleh diabaikan. Dalam rangka memilah-milah ini, kita juga perlu mengurangi dan membatasi sumber-sumber informasi itu untuk menginterupsi hidup dan menyita waktu kita. Karena semakin banyaknya informasi juga tidak menjamin manusia menjalani hidup yang lebih baik maka kita perlu menekankan kualitas daripada kuantitas. Alangkah baiknya kita memberi waktu yang lebih banyak untuk mengolah, menganalisis dan memikirkan setiap informasi itu menjadi pengetahuan yang membuat kita makin berhikmat di dalam menjalani hidup sehari-hari.

\footnotetext{
${ }^{29}$ Ibid., 140.
} 


\section{Kebenaran, Epistemologi dan Otoritas}

Pada masa sebelum teknologi tulisan dan mesin cetak ada, ketika orang-orang ingin mengetahui kebenaran tentang sesuatu, mereka akan mencari orang-orang yang dianggap ahli atau pakar di bidang tersebut. Seiring berkembangnya teknologi tulisan dan buku, orang-orang mencari kebenaran dari dalam buku-buku yang dianggap sebagai sumber dan standar kebenaran, seperti ensiklopedi dan kamus. Namun, pada zaman sekarang ini ketika teknologi informasi berkembang ke dunia digital dan dunia maya, orang-orang yang mencari kebenaran jarang berkonsultasi langsung kepada pakar atau mencari ensiklopedi, melainkan mereka mencarinya sendiri di Internet dengan menggunakan mesin pencari seperti Google atau situs Wikipedia. Perkembangan teknologi informasi yang sedemikian pesat ini telah mengubah paradigma manusia akan kebenaran dan otoritas.

Pada saat ini Wikipedia dapat dikatakan sebagai situs yang paling populer dicari orangorang ketika mereka ingin mengetahui kebenaran tentang suatu hal. Begitu populernya situs ini, sampai-sampai Google hampir selalu menempatkan Wikipedia di urutan pertama dari halaman pertama hasil pencariannya. Wikipedia menawarkan 15 juta artikel dengan jumlah pengguna terdaftar 13 juta orang yang masing-masing punya akses untuk menambah atau mengedit artikel yang sudah ada. ${ }^{30}$ Wikipedia dikembangkan dari sebuah aplikasi jaringan bernama wiki, yang memungkinkan para penggunanya untuk melakukan modifikasi, ekstensi atau penghapusan isi dan struktur sebuah situs secara kolaboratif. ${ }^{31}$ Kata kunci yang penting untuk diperhatikan di sini adalah "kolaboratif" atau "kolaborasi." Kata "kolaborasi" ini memberi petunjuk bahwa filosofi di balik aplikasi wiki ini adalah demokratisasi dari pengadaan dan pengubahan isi sebuah situs internet. Meskipun para penggunanya dapat mengubah isi dari artikelnya secara bebas, pihak Wikipedia mengatakan bahwa mereka memiliki 4000 orang pakar yang terlibat untuk melakukan pengecekan fakta dan verifikasi terhadap kualitas dan akurasi dari artikel yang mereka terbitkan. ${ }^{32}$ Meskipun demikian, para pakar dengan segudang kredensial akademis sekalipun, tidak dapat menjamin bobot atau otoritas yang lebih besar terhadap artikel-artikel tersebut karena Wikipedia selalu berada dalam keadaan "mengalir" secara konstan, dengan banyak artikel yang diubah setiap harinya.

Apakah permasalahan-permasalahan yang muncul dari model epistemologi atau pencarian kebenaran yang ditawarkan oleh teknologi informasi saat ini? Permasalahan terbesar dari model wiki seperti di atas adalah mengubah total pemahaman manusia akan kebenaran. Kebenaran tidak lagi dipandang sebagai sebuah patokan atau standar yang tetap dan pasti, yang dinyatakan oleh satu figur yang otoritatif, melainkan ditentukan oleh apa yang disepakati oleh opini mayoritas. $^{33}$ Makna kebenaran turun derajatnya menjadi hanya sekadar konsensus atau kesepakatan bersama. Selain itu, kebenaran menjadi bersifat subjektif, yaitu ditentukan secara

\footnotetext{
${ }^{31} \mathrm{http} / / /$ en.wikipedia.org/wiki/Wiki. Diakses pada 21 Agustus 2018. Wiki dibuat dan dikembangkan pertama kali pada tahun 1994 oleh Ward Cunningham ketika ia membuat situs bernama "WikiWikiWeb" yang dijalankan pada situs perusahaannya c2.com, dan sebuah perangkat lunak wiki yang mengoperasikannya. Dengan demikian dapat dikatakan c2.com adalah sebuah situs wiki yang pertama kali dijalankan dengan halaman-halaman dan link-link yang dapat diedit dengan mudah melalui browser. Cunningham memilih nama "WikiWikiWeb" berdasarkan pengalamannya naik "Wiki Wiki Shuttle" di Bandara Internasional Honolulu, Hawaii. "Wiki" adalah kata dalam bahasa Hawaii yang artinya "lekas" atau "segera" (quick).

${ }^{32}$ Challies, The Next Story, 158.

${ }^{33}$ Ibid., 166.
} 
demokratis oleh siapa pun yang ingin menyatakan pendapatnya. ${ }^{34}$ Makna kebenaran turun derajatnya menjadi hanya sekadar opini saja.

Permasalahan kedua yang sangat berkaitan erat dengan makna kebenaran adalah tentang otoritas. Perkembangan pesat teknologi informasi di dunia internet saat ini telah mengubah paradigma mengenai otoritas menjadi sebuah egalitarianisme yang radikal. Artinya, pengertian otoritas yang ada di dalam pengetahuan tidak lagi dikaitkan dengan satu figur yang memiliki kapasitas pengetahuan dan kompentensi yang memadai, melainkan diberikan secara demokratis dan bebas kepada semua orang. Karena paradigma baru ini maka, dalam hal pengetahuan, seorang teolog tidak memiliki otoritas yang lebih besar dari seorang anak kecil, guru tidak memiliki otoritas yang lebih besar dari muridnya, dan orangtua tidak memiliki otoritas yang lebih besari dari anak-anaknya. Bila otoritas yang melekat di dalam pengetahuan telah diturunkan derajatnya, maka kemungkinan besar hal yang sama juga dapat terjadi pada bidang-bidang kehidupan lainnya. Akibat yang muncul dari paradigma baru mengenai kebenaran dan otoritas ini adalah lahirnya crowdsourcing. ${ }^{35}$ Tinjauan atau resensi buku dan film, yang sebelumnya didominasi oleh para ahli atau pakar, sekarang telah menjadi area yang melibatkan para penulis atau blogger siapa pun dan pembeli mana pun. Suatu

\footnotetext{
${ }^{34}$ Ibid., 165. Di tahun 2007, Virgil Griffith membuat sebuah perangkat lunak yang disebutnya WikiScanner. Tujuan dari perangkat ini adalah untuk menghubungkan setiap bentuk pengubahan terhadap artikel Wikipedia dengan komputer yang menunjuk kepada orang-orang atau organisasi yang telah melakukan pengubahan tersebut. Hasilnya sungguh mengejutkan, karena memperlihatkan banyak perusahan dan politikus secara konstan memantau dan mengubah artikel-artikel tertentu di dalam Wikipedia yang menjadi ketertarikan atau sesuai dengan agenda mereka. Misalnya, komputer-komputer dari dalam kantor pusat Church of Scientology telah menghapus kritik-kritik terhadap gereja tersebut dari dalam artikel tentang Scientology.

${ }^{35}$ Crowdsourcing adalah singkatan dari crowd-outsourcing, yang melibatkan sekumpulan orang banyak (termasuk yang amatir), biasanya melalui internet, untuk berkolaborasi mengerjakan suatu tugas yang sebelumnya diselesaikan oleh satu organisasi atau individu (yang ahli) saja.
}

peristiwa atau kejadian yang biasa diliput oleh para wartawan profesional, sekarang dapat diceritakan oleh siapa pun yang menyaksikan peristiwa itu dan langsung mem-posting-nya di dunia maya, baik dalam bentuk tulisan, gambar maupun video.

Bagaimana perspektif firman Tuhan menjawab permasalahan dan kecenderungan seperti di atas? Alkitab menyatakan dengan jelas bahwa Allah Tritunggal adalah sumber dan otoritas kebenaran itu sendiri. Dalam Injil Yohanes 17:3, Tuhan Yesus berkata bahwa Allah adalah Allah yang benar. Di dalam Injil yang sama pasal 14:6, Tuhan Yesus juga berkata bahwa diri-Nya adalah jalan dan kebenaran dan hidup. Dan, di dalam Injil yang sama juga pasal 16:13, Tuhan Yesus menyatakan bahwa Roh Kudus adalah Roh kebenaran. Berdasarkan Ayub 37:16, Allah dikatakan adalah Allah yang Mahatahu, yang sempurna di dalam pengetahuan-Nya. Dengan demikian, dapat disimpulkan bahwa kebenaran adalah apa yang Allah katakan. Dialah standar dan otoritas kebenaran. Kebenaran juga berarti integritas moral, yaitu kesempurnaan Allah yang dinyatakan di dalam dunia, yang asli, nyata dan murni. ${ }^{36}$

Sebagai yang diciptakan menurut gambar Allah, manusia dipanggil untuk mengimitasi Dia, untuk menjadi serupa dengan-Nya. Rasul Paulus berkata kepada jemaat Efesus, "Jadilah penurut-penurut Allah, seperti anak-anak yang kekasih" (Ef. 5:1). Karena Allah adalah kebenaran, maka manusia juga dipanggil untuk memiliki pengetahuan akan kebenaran yang akurat dan dapat diandalkan. Meskipun pengetahuan tersebut hanya dapat bersifat parsial di dalam hati dan pikiran dari ciptaan terbatas seperti manusia, namun kita tetap dapat meyakini bahwa kita dapat mengetahui apa yang benar karena pengetahuan ini berasal dari Allah sang sumber kebenaran. ${ }^{37}$ Dia telah memberikan kita firmanNya yang selalu benar dan murni (Ams. 12:7; Yoh. 17:17). Orang-orang percaya yang telah mengenakan manusia baru "terus-menerus

\footnotetext{
${ }^{36}$ Challies, The Next Story, 160.

${ }^{37}$ Ibid., 161.
} 
diperbaharui untuk memperoleh pengetahuan yang benar menurut gambar Khaliknya" (Kol. 3:10).

Selain menjadi penurut-penurut-Nya, Allah juga menghendaki manusia menolak dan menjauhkan diri dari dusta/kebohongan, sebagai manifestasi dosa dan kejahatan. Jika kebenaran secara inheren ada di dalam diri Allah maka dusta secara inheren ada di dalam diri Iblis (Yoh. 8:44). Berdusta merupakan kejijikan bagi Allah karena hal itu mencemooh kebenaran-Nya. Di tengah masyarakat yang sangat ceroboh dalam hal menyatakan kebenaran, anak-anak Allah sebaliknya dipanggil untuk mengimitasi Sang Pencipta, serta menjaga dengan sungguh-sungguh bagaimana kehidupan dan perkataannya selalu mencerminkan kebenaran (Za. 8:16; Ef. 4:25).

Bagaimanakah sikap orang Kristen menghadapi teknologi mesin pencari dan wiki yang saat ini berperan sebagai media penyampai kebenaran? Kita perlu sangat hati-hati untuk tidak menjadikan teknologi informasi ini sebagai sumber kebenaran yang sah dan dapat diandalkan, karena kebenaran bukanlah apa yang relevan dan menjadi konsensus bersama, melainkan apa yang Allah pikirkan dan kehendaki. Apa yang dinyatakan oleh mesin pencari dan wiki tidak memiliki otoritas yang sejati untuk menyatakan apa yang benar dan yang salah karena apa yang mereka publikasikan hanya sebatas informasi dan pengetahuan yang crowdsourced (dikerjakan dan diformulasikan secara bersama-sama oleh siapa pun yang bebas mengemukakan ide dan opininya). Mesin pencari dan wiki hanya dapat berfungsi sebagai penuntun awal yang mendorong kita untuk mencari kebenaran dan belajar lebih giat lagi dari sumber-sumber yang terbaik.

\section{Visibilitas, Privasi dan Integritas}

Terkait erat dengan semakin canggihnya teknologi perangkat keras, semakin melimpahnya akses informasi dan semakin luasnya jaringan internet secara global adalah keberadaan seseorang, apakah disadarinya atau tidak disadarinya, semakin mudah ditelusuri, bahkan dari belahan dunia mana pun. Smartphone dengan sinyal seluler, sensor GPS dan koneksi WiFi-nya dapat melacak keberadaan seseorang secara geografis. Aktivitas seseorang di media sosial seperti Facebook dan Twitter telah meninggalkan jejak kepribadiannya berupa gambar dan komentar yang telah di-posting-nya. Dari setiap aktivitas seseorang yang menggunakan aplikasi yang dibuatnya, Google dapat melacak dan menganalisis banyak hal dari si pengguna (misalnya kesukaan, minat, lokasi, dan bahkan termasuk hal-hal yang privat dari diri kita seperti daftar kontak dan setiap aktivitas kita di smartphone) dan memakai informasi itu untuk menjual ruang-ruang bagi pemasang iklan. ${ }^{38}$ Belum lagi keberadaan setiap komputer yang kita gunakan di dalam berjejaring internet dapat dilacak keberadaannya melalui alamat IP (Internet Protocol). Hal ini masih ditambah lagi dengan keberadaan kamera CCTV yang senantiasa "mengintai" keberadaan kita di mana pun. Semua ini memperlihatkan satu hal kepada kita bahwa hidup manusia saat ini ada di dalam pengawasan yang konstan. Kita menjadikan kehidupan kita senantiasa di hadapan publik.

Ada dua permasalahan yang ditimbulkan dari hal di atas. Pertama, keberadaan diri manusia saat ini telah direduksi menjadi sekadar data dan informasi digital yang menjadi objek penelitian. Para penguasa teknologi informasi saat ini mempekerjakan banyak matematikawan dan ilmuwan komputer untuk mengumpulkan setiap jejak informasi yang kita tinggalkan untuk melakukan analisis dan prediksi yang akan dipakai demi kepentingan komersial. $^{39}$ Keberadaan manusia saat ini telah direduksi hanya menjadi sekadar kalkulasi matematika.

Permasalahan kedua adalah berkaitan dengan privasi dan keamanan. Setiap jejak-jejak digital yang manusia tinggalkan di dalam perangkat teknologi informasi dan jaringan internet dapat mengancam keamanan serta privasi diri dan keluarganya. Banyak kejahatan dan

\footnotetext{
${ }^{38}$ Detweiler, iGods, 111-113.

${ }^{39}$ Challies, The Next Story, 178-81.
} 
penipuan di dunia maya maupun dunia nyata dilakukan dengan cara mencuri jejak-jejak diri kita yang terekam di dalam perangkat teknologi informasi. Dan tidak hanya itu, setiap tindakan kita baik yang positif dan membangun, maupun yang negatif dan gegabah dapat segera diketahui dan tersebar luas melalui jaringan internet. ${ }^{40}$

Bagaimana perspektif firman Tuhan berbicara mengenai isu ini? Pertama, Alkitab mengingatkan bahwa manusia bukan hanya sekadar objek yang dapat digunakan semaunya untuk kepentingan yang egois. Setiap kita telah diciptakan dengan unik menurut gambar Allah dan untuk maksud yang telah Dia tetapkan. Pemazmur sangat menyadari hal ini ketika mengatakan, "Sebab Engkaulah yang membentuk buah pinggangku, menenun aku dalam kandungan ibuku. Aku bersyukur kepada-Mu oleh karena kejadianku dahsyat dan ajaib ... mata-Mu melihat selagi aku bakal anak, dan dalam kitab-Mu semuanya tertulis hari-hari yang akan dibentuk sebelum ada satupun daripadanya" (Mzm. 139:13-16). Karena itu, setiap orang tidak boleh di-depersonalisasi-kan menjadi hanya sekadar data digital 1 atau 0. Kedua, Tuhan menghendaki umat-Nya hidup berintegritas (Mi. 6:8; Ams. 12:22; 21:3). Antara apa yang dikatakan dan dilakukan, antara apa yang diperbuat di dunia maya maupun di dunia nyata, antara apa yang

${ }^{40}$ Misalnya pada Juni 2010, seorang anggota Kongres di Washington, D.C. yang bernama Bob Etheridge secara spontan menangkap pergelangan tangan dan memegang leher seseorang dari belakang, ketika orang tersebut menanyakan sesuatu kepadanya sambil membawa kamera video di tangannya. Akibat perbuatannya ini, Etheridge segera menjadi sensasi di YouTube, karena peristiwa itu ternyata direkam, diunggah dan disaksikan jutaan kali. Karena visibilitas publik mengenai penyerangan yang dilakukannya tanpa alasan ini, ia terpaksa harus mengumumkan penyesalan dan permintaan maafnya secara publik (Challies, The Next Story, 182). Selain yang negatif, juga ada tindakan positif yang terekam dan diketahui secara publik sehingga menuai pujian. Misalnya akun Facebook Humas Mabes Polri pada tanggal 9 Maret 2015 mengunggah foto dua anggota Brimob yang berada di tengah medan operasi tidak melupakan kewajibannya untuk melaksanakan ibadah salat lima waktu, mendapat beragam tanggapan positif dari pengguna media sosial (http://iorg.merdeka.com/peristiwa/foto-brimob-khusyusalat-di-tengah-kondisi-siaga-tuai-pujian.html. Diakses pada 21 Agustus 2018). dilakukan di dunia publik maupun di dunia pribadi seorang diri, haruslah sejalan dengan kebenaran. Bahkan, Tuhan menilai setiap perkataan dan tindakan yang kita perbuat menurut standar kebenaran dan kekudusanNya (Im. 19:2; Mat. 5:48; 1Ptr. 1:15-16).

Lalu, bagaimanakah sikap kita sebagai orang Kristen menjalani kehidupan di tengah kecanggihan teknologi informasi yang memudahkan akses dan penelusuran jejak terhadap setiap keberadaan diri kita? Pertama, kita harus berelasi dengan orang-orang lain di sekitar kita (seperti klien, pembeli atau pelanggan) sebagai sesama manusia dengan segala pikiran, perasaan, kehendak dan kebutuhannya, dan bukan sekadar target pemasaran bisnis usaha kita. Kedua, kita harus menjaga privasi setiap data dan informasi diri kita yang sensitif agar tidak sembarangan tersebar di dunia maya sehingga bisa dimanfaatkan oleh pihak-pihak yang tidak bertanggung jawab untuk berbuat kejahatan. Backup data-data pribadi yang sangat sensitif sebaiknya tidak menggunakan teknologi penyimpanan cloud yang berbasis internet. Ketiga, kita harus menjaga integritas di dalam setiap perkataan dan perbuatan kita, baik di dunia maya maupun di dunia nyata, karena selain Tuhan yang mengetahuinya, saat ini orang-orang lain juga memiliki kemungkinan yang besar untuk bisa melihat jejak-jejak perbuatan kita itu dan bisa menyebarluaskannya.

\section{Kesimpulan}

Dengan kemajuan teknologi informasi saat ini, manusia menjadi jadi semakin mudah dan cepat di dalam berkomunikasi dan berelasi dengan siapa pun di seluruh dunia ini serta mencari informasi dan pengetahuan mengenai apa pun yang ada di dunia ini. Namun, sejalan dengan kemajuan itu juga terdapat isu-isu etika yang penting dan berdampak di dalam pola pikir, budaya dan perilaku manusia saat ini. Isu-isu etika tersebut adalah berkaitan dengan: (1) kesejatian sebuah relasi dan komunitas di dunia maya; (2) kebergantungan dan kegandrungan manusia saat ini dengan setiap informasi yang beredar di 
dunia maya, yang tidak menghasilkan kualitas manusia yang semakin berhikmat, malah menjadikan manusia semakin dangkal berpikir; (3) validitas dan reliabilitas dari setiap informasi, pengetahuan atau kebenaran yang ada di dalam dunia maya; serta (4) keamanan dan integritas di dalam penggunaan teknologi informasi.

Menanggapi munculnya isu-isu etika di atas, Alkitab sebagai firman Tuhan yang berotoritas dalam kehidupan orang percaya memberikan beberapa pedoman bagi kita bagaimana bersikap dan menjalani kehidupan di tengah dunia yang sarat dengan teknologi informasi. Pertama, Tuhan menghendaki umat-Nya menghindari pendekatan yang instan dan pragmatis di dalam menjalin relasi, namun sebaliknya, berjuang membangun relasi yang tulus dan sehat secara muka dengan muka dalam sebuah komunitas. Kedua, Tuhan berkehendak agar umat-Nya mengejar dan mencintai hikmat yang lahir dari sikap takut akan Dia, dan bukan hanya sekadar mendapatkan pengetahuan yang melimpah yang ditawarkan oleh teknologi informasi. Ketiga, Tuhan ingin agar umat-Nya untuk menjadikan karakterNya yang tidak berubah serta firman-Nya yang berotoritas sebagai sumber dan standar kebenaran yang sejati untuk menilai segala jenis informasi yang mereka terima. Keempat, Tuhan menghendaki umat-Nya memperlakukan sesama manusia dengan semestinya sebagai gambar Allah dan menggunakan teknologi informasi dengan berintegritas. 


\section{Daftar Kepustakaan}

Asosiasi Penyelenggara Jasa Internet Indonesia. Infografis Penetrasi dan Perilaku Pengguna Internet Indonesia 2017. APJII dan Teknopreneur, 2018.

Challies, Tim. The Next Story: Life and Faith After Digital Explosion. Grand Rapids: Zondervan, 2011.

Detweiler, Craig. iGods: How Technology Shapes Our Spiritual and Social Lives. Grand Rapids: Brazos, 2013.

Dyer, John. From the Garden to The City: The Redeeming and Corrupting Power of Technology. Grand Rapids: Kregel, 2011.

Gitlin, Todd. "Media Saturation and the Increasing Velocity of Everyday Life." Dalam Living in the Information Age: A New Media Reader, diedit oleh Erik P. Bucy, 139-146. Belmont: Wadsworth, 2004.

Groothuis, Douglas. The Soul in Cyberspace. Grand Rapids: Baker, 1997.

Hart, Archibald D. dan Sylvia Hart Frejd, The Digital Invasion. Grand Rapids: Baker, 2013.

Kemp, Simon. "Digital in 2018: World's Internet Users Pass the 4 Billion Mark.” We Are Social, New York 2018. Diakses 21 Agustus 2018. https://wearesocial.com/blog/2018/01/global-digital-report-2018.

Lohrmann, Daniel J. Virtual Integrity: Faithfully Navigating the Brave New Web. Grand Rapids: Brazos, 2008.

Panji, Aditya. "Indonesia Peringkat 22 Pelaku Kejahatan Online.” Kompas.com, Jakarta 2014. Diakses 21 Agustus 2018. http://tekno.kompas.com/read/2014/05/07/1719331/indonesia. peringkat.22.pelaku.kejahatan.online.

Schultze, Quentin J. Habist of the High-Tech Heart: Living Virtuously in the Information Age. Grand Rapids: Baker, 2002.

Statista. Countries with the Highest Number of Internet Users as of December 2017 (in millions). Diakses pada 21 Agustus 2018. https://www.statista.com/statistics/262966/number-ofinternet-users-in-selected-countries.

Sugianto, Danang. "4000 Laporan Cyber Crime Mayoritas Korbannya Perusahaan.” Detik Finance, Jakarta 2018. Diakses 21 Agustus 2018. https://finance.detik.com/bursa-dan-valas/d4398592/4000-laporan-cyber-crime-mayoritas-korbannya-perusahaan.

The Jakarta Post. Cyberattacks in Indonesia Rising at Alarming Rate: Officials. Jakarta 2016. Diakses 21 Agustus 2018. https://www.thejakartapost.com/news/2016/06/03/cyberattacks-in-indonesia-rising-at-alarming-rate-officials.html.

Wahyudi, Reza. "Kejahatan Dunia Maya di Indonesia Mengkhawatirkan." Kompas.com, Bandung 2014. Diakses 21 Agustus 2018. http://tekno.kompas.com/

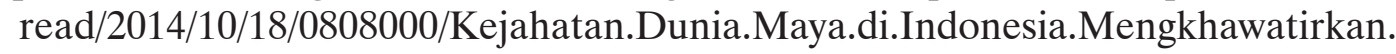

